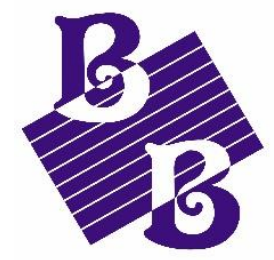

BioBacta
Journal of Bioscience and Applied Research

www.jbaar.org

\title{
Production of Heliomycin from Actinomycete and Evaluation of its
}

\section{Antimicrobial Activities}

\author{
Abdulla A. Mahmoud, Ehab A. Essawy, Mohga S. Abdalla, and Mohamed S. Abdelfattah* \\ ${ }^{1}$ Chemistry Department, Faculty of Science, Helwan University, Cairo 11795, Egypt \\ *Corresponding author: mabdelfattah@ @science.helwan.edu.eg
}

Received 28/9/2019; Accepted 24/10/2019

DOI: 10.21608/jbaar.2019.114535

\begin{abstract}
Heliomycin (1) was isolated from the culture broth of actinomycete AB5. The structure of the isolated compound (1) was characterized by spectroscopic methods including NMR and mass spectrometry data. The influence of cultural parameters affecting the production of biomass including different culture media, $\mathrm{pH}$ values, temperatures, and incubation periods was investigated. The maximum production of secondary metabolites $(2.78 \mathrm{~g} / \mathrm{l})$ was found in the culture medium of Waksman at initial $\mathrm{pH} 7.5$ for four days at $35^{\circ} \mathrm{C}$. The antimicrobial activity of heliomycin (1) was evaluated against Gram-positive bacteria, Gram-negative bacteria, and fungi.
\end{abstract}

Key words: Actinomycete, secondary metabolites, heliomycin, NMR and antimicrobial.

\section{Introduction}

Microbial natural products provide a huge numbers of approved drugs with diverse biological activities (Blunt et al., 2012; Citron et al., 2012; Raja et al., 2010). Among microorganisms, actinomycetes are the most promising group for the production of antibiotics and other important bioactive substances (Cai et al., 2009). Actinomycetes are Gram-positive, aerobic, mycelia bacteria with a high $\mathrm{G}+\mathrm{C}$ nucleotide content $(>55 \%)$ in their DNA. They are widely distributed in both terrestrial and aquatic habitats and form asexual spores. They are defined as prokaryotic organisms located between bacteria and fungi (Okami and Hotta, 1988). The filamentous actinomycetes species can produce about $70-80 \%$ of all isolated bioactive compounds. As per literature, the most common representative genera

* Corresponding author: mabdelfattah@science.helwan.edu.eg 
of actinomycetes include Streptomyces, Actinomyces, Arthrobacter, Corynebacterium, Frankia, Micrococcusand Micromonospora (Goodfellow et al., 1988).

Heliomycin (1) was firstly isolated from the culture broth of Streptomyces resistomycificus (Brockmann and Schmidt-Kastner, 1951). It is an unusual aromatic polyketide that has anticancer (Adinarayana et al., 2006; Vijayabharathi et al., 2011), antibacterial, and antiviral activity (Eckardt al 1972). Several studies revealed that heliomycin (1) inhibits RNA polymerase(Haupt et al., 2007), apoptosis (Shiono et al., 2002), and RNA and protein synthesis. Additionally, it acted as a histone deacetylase inhibitor (Abdelfattah et al., 2018). Herein, we described isolation and structure elucidation of heliomycin (1) from actinomycete AB5. Optimization of culture conditions was studied to increase the yield and to reduce the cost of production.Additionally, the antimicrobial activity of heliomycin (1) against different pathogens was investigated.

\section{Materials and Methods}

\subsection{Isolation and fermentation actinomycete AB5}

A sediment sample was collected from the Ismailia Canal in the region of Mustard, Cairo, Egypt. The sample was collected during winter 2017 and kept at $4{ }^{\circ} \mathrm{C}$ for further working up. One gram of wet sediment was dispersed in $9 \mathrm{ml}$ of sterilized water and vortexed for 2 minutes. The sample was subjected to heat treatment at $60^{\circ} \mathrm{C}$ for 10 minutes to eliminate non-sporulating bacteria. To prevent the fungal and bacterial contaminants, cycloheximide $(50 \mu \mathrm{g} / \mathrm{ml})$ and nalidixic acid (75 $\mu \mathrm{g} / \mathrm{ml})$ were added to the medium. Following serial dilution $\left(10^{-1}, 10^{-2}\right.$ and $\left.10^{-3}\right)$ of the suspension with sterilized water, a $100 \mu \mathrm{l}$ of aliquot was spread on starch-casein agar (SCA)(Abdelfattah et al., 2016). The plates were incubated at $28^{\circ} \mathrm{C}$ for 15 days until the colonies appeared. Colonies that produce a yellow pigment were picked up, purified by repeated streaking on Waksman agar plates(Abdelfattah et al., 2017)and took a voucher number AB5. The strain was recognized as actinomycete by the formation of tough, leathery , and yellow colonies that adhered to the agar surface. Well grown agar plates were used to inoculate 6 x $250 \mathrm{~cm}^{3}$ Erlenmeyer flasks each containing $100 \mathrm{ml}$ of Waksman media. The flasks were incubated with $240 \mathrm{rpm}$ for 4 days at $28^{\circ} \mathrm{C}$.

\subsection{Extraction and isolation of heliomycin (1)}

The fermentation broth was harvested after 4 days and centrifuged at $4000 \mathrm{rpm}$ for $10 \mathrm{~min}$. The resulting mycelial cake was extracted three times with methanol. The water phase was extracted three times with ethyl acetate. As the TLC (DCM/10\% MeOH) of both extracts from mycelia cake and water phase showed similar composition, they were combined and concentrated under reduced pressure. The brown crude extract was dissolved in methanol and left to stand overnight. A yellow precipitate separated out of the solution was observed. The precipitate was filtrated and washed three times with methanol to give a yellow solid.

Heliomycin (1):Yellow solid; (-)-ESI-MS: $m / z(\%)$ $=375\left([\mathrm{M}-\mathrm{H}] ;\right.$; 100); ${ }^{1} \mathrm{HNMR}\left(\left[\mathrm{D}_{6}\right] \mathrm{DMSO}, 600\right.$ $\mathrm{MHz}): \delta_{\mathrm{H}}=14.55(\mathrm{~s}, 1 \mathrm{H}, 7-\mathrm{OH}), 14.36(\mathrm{~s}, 1 \mathrm{H}, 3-$ $\mathrm{OH}), 14.07$ (s, 1H, 5-OH), 11.40 (br. s, 1H, 10-OH), $7.23(\mathrm{~s}, 1 \mathrm{H}, 11-\mathrm{H}), 7.01(\mathrm{~s}, 1 \mathrm{H}, 8-\mathrm{H}), 6.34(\mathrm{~s}, 1 \mathrm{H}$, 4-H), 2.90 (s, 3H, 9- $\left.\mathrm{CH}_{3}\right), 1.56\left(\mathrm{~s}, 6 \mathrm{H}, 1-\mathrm{CH}_{3}\right)$; ${ }^{13} \mathrm{CNMR}\left(\left[\mathrm{D}_{6}\right] \mathrm{DMSO}, 125 \mathrm{MHz}\right): \delta_{\mathrm{C}}=204.9(\mathrm{C}-$ 2), 183.5 (C-6), 170.7 (C-3), 170.5 (C-5), 167.6 (C7), 162.1 (C-10), 152.7 (C-11a), 152.1 (C-9), 142.2 (C-11c), 139.1 (C-9b), 128.5 (C-8), 128.4 (C-9a), 118.2 (C-11), 114.2 (C-11b), 107.1 (C-6a), 105.9 (C-5a), 102.1 (C-2a), 99.4 (C-4), 46.1 (C-1), 28.9 (2Me-1), 25.5 (Me-9).

\subsection{Optimization of the cultural conditions for production of heliomycin (1)}

\subsubsection{Effect of media composition}

Three different types of broth media were used in this study for evaluation of the optimum conditions. 
The compositions of these media were as follows: Starch casein medium (g/l): $10 \mathrm{~g}$ Soluble starch; 0.3 g Casein; 2 g $\mathrm{K}_{2} \mathrm{HPO}_{4} ; 2$ g $\mathrm{KNO}_{3} ; 0.05 \mathrm{~g}$ $\begin{array}{llllll}\mathrm{MgSO}_{4} .7 \mathrm{H}_{2} \mathrm{O} ; & 0.02 & \mathrm{~g} & \mathrm{CaCO}_{3} & \text { and } & 0.01 \mathrm{~g}\end{array}$ $\mathrm{FeSO}_{4} .7 \mathrm{H}_{2} \mathrm{O}$. Waksman medium (g/l): $20 \mathrm{~g}$ Glucose; 5 g Beef extract; 5 g peptone; 3 g yeast; 5 $\mathrm{g} \mathrm{NaCl}$ and $3 \mathrm{~g} \mathrm{CaCO}_{3}$. ISP2 media (g/l): $4 \mathrm{~g}$ Dextrose; $4 \mathrm{~g}$ Yeast and $10 \mathrm{~g}$ Malt extract. For all media used, the $\mathrm{pH}$ was adjusted to 7.5 before sterilization. One hundred $\mathrm{ml}$ of these liquid media was dispensed into each $250 \mathrm{~mL}$ Erlenmeyer flasks and autoclaved at $121^{\circ} \mathrm{C}$ for $20 \mathrm{~min}$. The flasks were incubated at $28^{\circ} \mathrm{C}$ on a rotary shaker at 240 rpm for $96 \mathrm{~h}$.

\subsubsection{Effect of initial $\mathrm{pH}$}

To study the effect of $\mathrm{pH}$ on the production of secondary metabolites, the $\mathrm{pH}$ value of the culture media was adjusted to $2.5,5.0,7.5$, and 10.0. The cultures were cultivated in Waksman and ISP2 media and incubated on rotary shaker (240 rpm) at $28^{\circ} \mathrm{C}$ for $96 \mathrm{~h}$.

\subsubsection{Effect of temperature}

Four different temperatures were used for the production of natural compounds $(25,28,35$, and $40^{\circ} \mathrm{C}$ ). The strain was cultivated on the Waksman medium at $\mathrm{pH} 7.5$ under shaking at $240 \mathrm{rpm}$ for 96 h.

\subsubsection{Effect of the incubation period}

Production of secondary metabolites was measured at different incubation intervals (48, 72, and $96 \mathrm{~h}$ ). The flasks were fermented in Waksman media at $28^{\circ} \mathrm{C}$ and pH.5 under shaking at $240 \mathrm{rpm}$.

\subsection{Antimicrobial activity of heliomycin (1)}

The susceptibility tests were performed according to NCCLS recommendations(Kiehlbauch et al., 2000). Two Gram-positive bacteria (Staphylococcus aureus and Bacillus subtilis), two Gram-negative bacteria (Escherichia coli ATCC 25955 and Proteus vulgaris ATCC 13315) and two fungi(Aspergillus flavus and Candida albicans) were used in the present study. The antimicrobial activities were performed by using the disk diffusion method (Rabah et al., 2013). Gentamycin $(4 \mu \mathrm{g} / \mathrm{ml})$ and ketoconazole $(100 \mu \mathrm{g} / \mathrm{ml})$ were used as positive controls for bacteria and fungi, respectively. Heliomycin (1) was dissolved in dimethyl sulfoxide (DMSO) at a concentration of $20 \mathrm{mg} / \mathrm{ml}$. Controls using DMSO were adequately done. The activity was determined by measuring the diameter of the inhibition zones after 24hours at $37^{\circ} \mathrm{C}$.

\section{Results}

\subsection{Isolation and structure determination of heliomycin (1)}

The crude extract of the actinomycete AB5 showed an interesting yellow band on TLC. Working up of the strain resulted in the isolation of one yellow compound (Figure 1). The compound gave a yellow fluorescence band at $365 \mathrm{~nm}$ and a reddish-brown coloration after staining with anisaldehyde/sulphuric acid. The UV spectrum of $\mathbf{1}$ showed absorption maxima at 457, 320, 290, and $267 \mathrm{~nm}$. Transitions from $\mathrm{n} \rightarrow \pi^{*}$ and $\pi \rightarrow \pi^{*}$ are the factors responsible for the observed peaks in the electronic spectra of compound 1. The molecular weight of 1 was determined to be 376 Dalton by electrospray ionization mass spectrometry (ESIMS) in the negative ion mode. The ${ }^{1} \mathrm{H}-\mathrm{NMR}$ spectrum of compound 1 (Figure 1) revealed three broad signals at $\delta_{\mathrm{H}} 14.28,14.23$ and 13.87each for one proton. This indicates the presence of three chelated hydroxyl groups in the molecule. A broad signal of one proton intensity appeared at $\delta_{\mathrm{H}} 11.76$ ppm, assigned for the aromatic hydroxyl group. In the aromatic region, three proton singlets appeared at $\delta_{\mathrm{H}} 7.15,6.76$ and $6.19 \mathrm{ppm}$. In the aliphatic region, the singlet of three protons at $\delta_{\mathrm{H}} 2.79$ is characteristic for the aromatic methyl group. In addition to sharp singlet at $\delta_{\mathrm{H}} 1.52$ assigned for six protons indicated the presence of two magnetically equivalent methyl groups. 


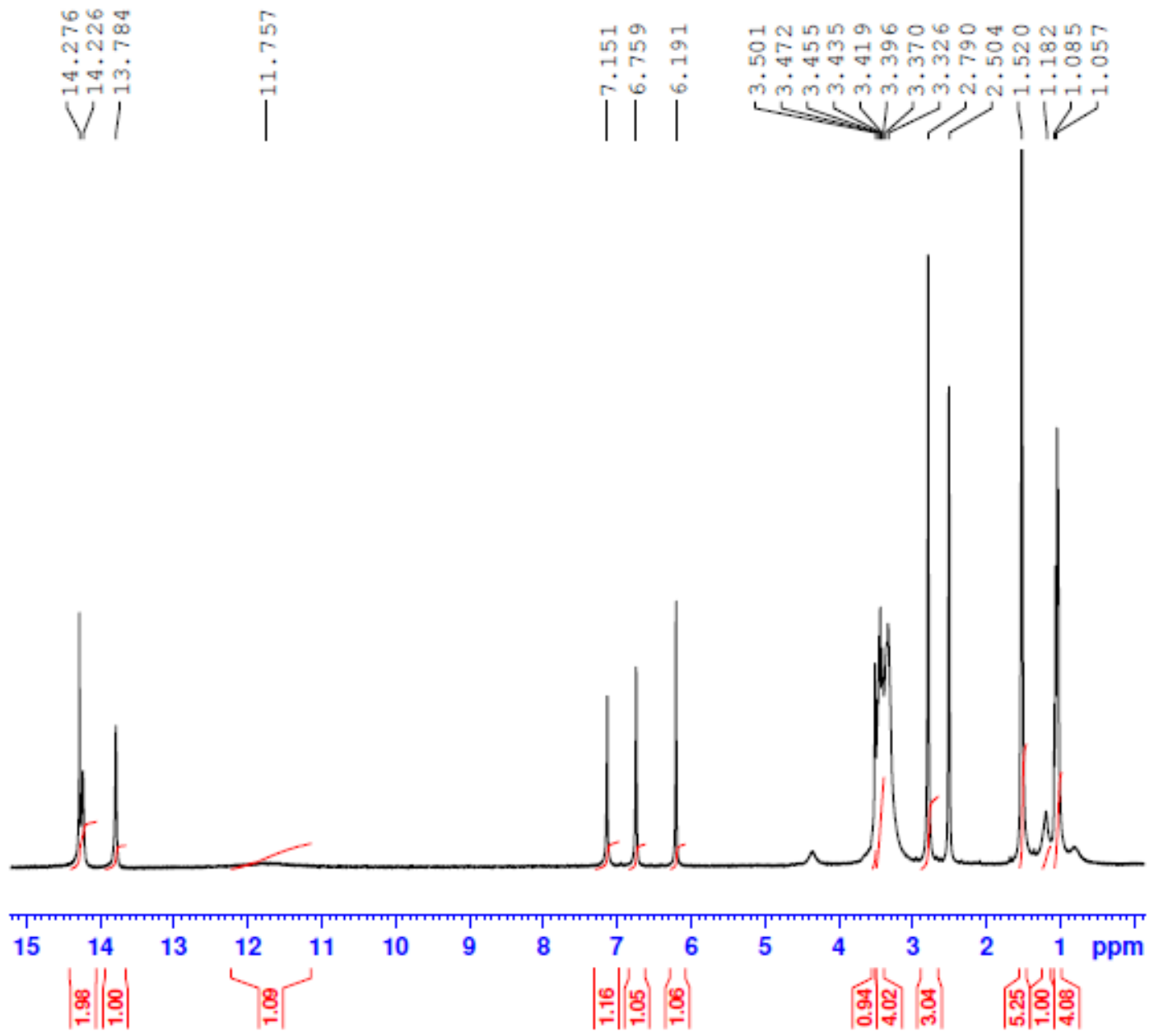

Figure 1: ${ }^{1} \mathrm{H}-\mathrm{NMR}$ spectrum $\left(400 \mathrm{MHz}, \mathrm{DMSO}-d_{6}\right)$ of heliomycin (1)

A search in SciFinder led to the assignment of 1 as heliomycin (Figure 2). The structure of compound $\mathbf{1}$ was also confirmed by comparison of these spectral data with those in the literature (Kock et al., 2005).<smiles>Cc1cc(O)c2c3c4c(cc(O)c13)C(C)(C)C(=O)c1c(O)cc(O)c(c1-4)C2=O</smiles>

Figure 2: Chemical Structure of heliomycin (1) 


\subsection{Optimization of cultural conditions}

To select the optimum media for the production of secondary metabolites from actinomycete AB5, three different media were used. The influence of each media on the production of biomass was recorded (Figure 3a). Among the selected media, Waksman medium broth showed an increase in the number of bioactive metabolites (1.46 g/l), followed by ISP2 broth $(0.90 \mathrm{~g} / \mathrm{l})$ and starch-casine broth $(0.29 \mathrm{~g} / \mathrm{l})$. The effect of the initial $\mathrm{pH}$ of the culture media on the production of biomass was investigated (Figure 3b). The maximum yield (1.99 $\mathrm{g} / \mathrm{l})$ was obtained at an initial $\mathrm{pH}$ of 7.5 followed by pH $10(1.79 \mathrm{~g} / \mathrm{l})$ and $\mathrm{pH} 5(1.73 \mathrm{~g} / \mathrm{l})$, respectively. At highly acidic conditions ( $\mathrm{pH} 2.5)$, the amount of crude extract was too little. The effect of different

(a) (b)

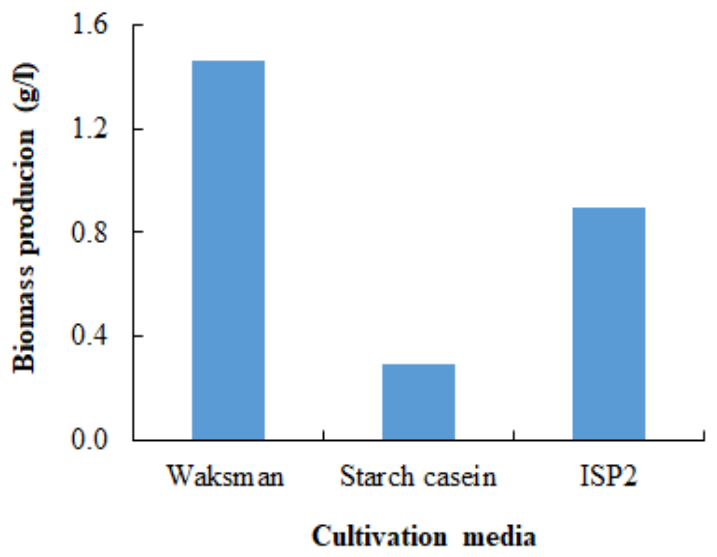

(c)

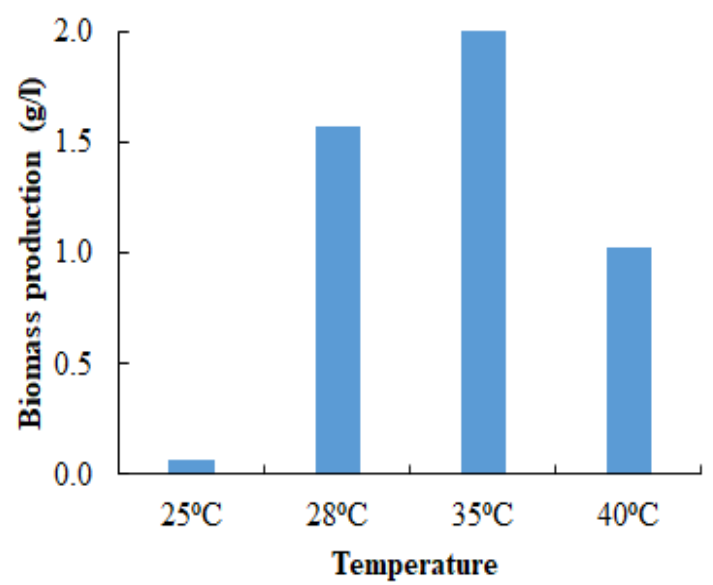

incubation temperature on the yield of the crude extract was reported in (Figure 3c).The highest yield of biomass was observed at $35^{\circ} \mathrm{C}(2.78 \mathrm{~g} / \mathrm{l})$. The production was gradually decreased at $28^{\circ} \mathrm{C}$ $(1.57 \mathrm{~g} / \mathrm{l})$ followed by $40^{\circ} \mathrm{C}(1.03 \mathrm{~g} / \mathrm{l})$. Minor amount of biomass was observed at $25^{\circ} \mathrm{C}$. The effect of incubation time on the production of metabolites is shown in (Figure 3d). The maximum yield reached after 96 hours $(2.11 \mathrm{~g} / \mathrm{l})$. Further decrease in the incubation time showed a gradual decrease in the production of biomass and the growth of actinomycetes. Therefore, optimum incubation time for the maximum production of secondary metabolite was at 96 hours. No growth was observed after $24 \mathrm{~h}$ of incubation.

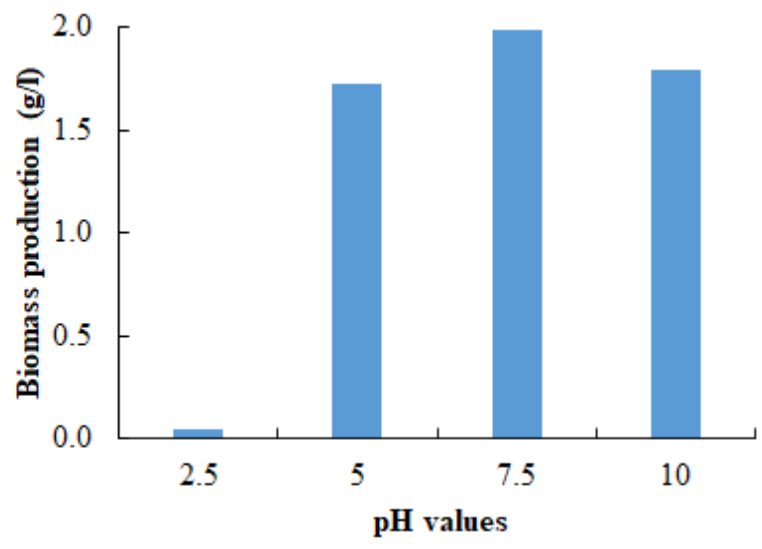

(d)

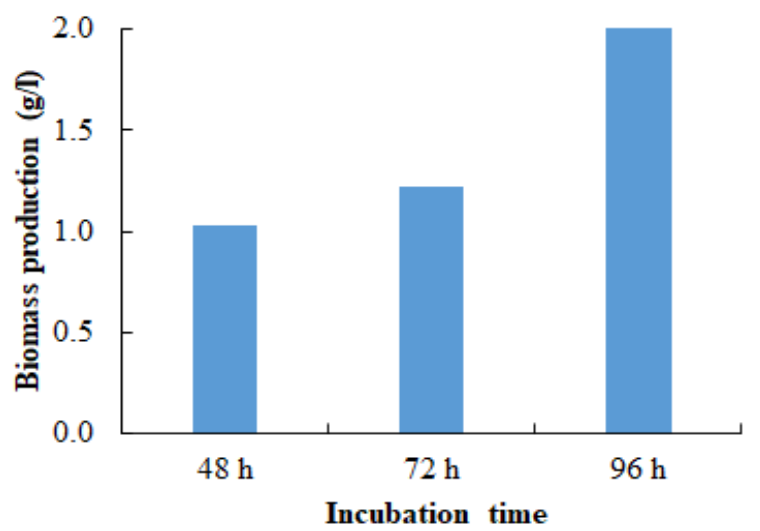

Figure 3: Effect of cultural conditions on the production of heliomycin (1); (a) composition of culture media, (b) pH values, (c) temperature and (d) incubation time. 


\subsection{Antimicrobial screening of heliomycin (1)}

Heliomycin (1) was screened for its inhibitory activity against different human pathogenic bacteria and fungi (Table 1). It showed activities against all four different tested bacteria. On the other hand it was inactive against Aspergillus flavusand Candida albicans.

Table 1: Antimicrobial activity of heliomycin (1)

\begin{tabular}{lc}
\hline \multicolumn{1}{c}{ Test organism } & Zone of inhibition (in mm) \\
\hline Bacillus subtilis & 12 \\
Escherichia coli & 10 \\
Staphylococcus aureus & 13 \\
Proteus vulgaris & 11 \\
Aspergillus flavus & $\mathrm{NZ}$ \\
Candida albicans & $\mathrm{NZ}$ \\
\hline
\end{tabular}

$\mathrm{NZ}$ is no zone of inhibition

Average of triplicate determinations

\section{Discussions}

During our screening program for bioactive secondary metabolites from actinomycetes(Abdelfattah et al., 2018, 2016; Elmallah et al., 2017), the strain AB5 was isolated. The strain was found to produce an unusual polyketide 1 with benzo[c,d]pyrene ring. Heliomycin (1) was firstly isolated from the culture of Streptomyces resistomycificus by Brockmann and Schmidt-Kastner(Brockmann and Schmidt-Kastner, 1951). Its structure was established by classical methods and based on chemical and spectral data together with $\mathrm{x}$-ray crystallographic analyses (H. Brockmann, E. Meyer, K. Schrempp, 1969; Höfle and Wolf, 1983). To choose the best conditions to produce heliomycin (1) from actinomycete AB5, several culturing media were used. Waksman medium was the best broth due to the presence of enough amounts of sugar, yeast extract, and other minerals. The $\mathrm{pH} 7.5$ gave a maximum yield of compound 1. It was reported that that most favorable range for growth and production of pigmented secondary metabolites from actinomycetes were established to be at $\mathrm{pH} 7.6-$ 8 (Palanichamy et al., 2011). The $\mathrm{pH}$ is a significant factor that affects the physiology of microorganisms by influences nutrient solubility, enzyme activity, cell membrane morphology, by product formation and oxidative reduction reactions (Bajaj et al., 2009). Additionally, our results revealed the best temperature for growing of actinomycete $\mathrm{AB} 5$ as $35^{\circ} \mathrm{C}$ for 4 days. Several literatures stated that the optimum temperature for the growth of actinomycetes was in the range between $30^{\circ} \mathrm{C}-40^{\circ} \mathrm{C}$ (Vijayabharathi et al., 2012; Palanichamy et al., 2011). Ripa et al., 2009 reported that actinomycetes had the ability to produce bioactive compounds on the fourth day. The antibacterial activities of heliomycin (1) against Gram-positive and Gram-negative bacteria are in accordance with Adinarayana et al., 2006. Vijayabharathi et al., 2011 reported that heliomycin (1) exhibited strong antimicrobial activity against Enterococcus faecalis and Staphylococcus epidermis and moderate activities against Staphylococcus aureus, Salmonella 
typhii, Klebsiella pneumoniae, and Bacillus subtilis.

\section{Conclusion}

Aquatic actinomycete AB5 was isolated from a sediment sample collected from the Ismailia Canal around the area of Mustard, Cairo, Egypt. The strain produced a yellow-pigmented compound identified as heliomycin (1). The optimal production conditions were Waksman liquid medium, $\mathrm{pH} 7.5$ for four days at $35^{\circ} \mathrm{C}$. The isolated compound (1) showed antimicrobial activity against gram positive and negative bacteria.

\section{References}

Abdelfattah, M.S., Elmallah, M.I.Y., Faraag, A.H.I., Hebishy, A.M.S., Ali, N.H., 2018. Heliomycin and tetracinomycin D: anthraquinone derivatives with histone deacetylase inhibitory activity from marine sponge-associated Streptomyces sp. SP9. 3 Biotech. https://doi.org/10.1007/s13205-0181304-1

Abdelfattah, M.S., Elmallah, M.I.Y., Hawas, U.W., El-Kassem, L.A., El-Desoky, A.H., 2016. Isolation and characterization of marinederived actinomycetes with cytotoxic activity from the Red Sea coast. Asian Pac. J. Trop. Biomed.

6

651-657. https://doi.org/10.1016/j.apjtb.2016.06.004

Abdelfattah, M.S., Elmallah, M.I.Y., Mohamed, A.A., Ishibashi, M., 2017. Sharkquinone, a new ana-quinonoid tetracene derivative from marine-derived Streptomyces sp. EGY1 with TRAIL resistance-overcoming activity. J. Nat. Med. https://doi.org/10.1007/s11418-0171086-5

Adinarayana, G., Venkateshan, M.R., Bapiraju, V.V.S.N.K., Sujatha, P., Premkumar, J., Ellaiah, P., Zeeck, A., 2006. Cytotoxic compounds from the marine actinobacterium Streptomyces corchorusii AUBN1/71. Russ. J. Bioorganic Chem. 32, 295-300.
https://doi.org/10.1134/S1068162006030125

Bajaj, I.B., Lele, S.S., Singhal, R.S., 2009. A statistical approach to optimization of fermentative production of poly $(\gamma$-glutamic acid) from Bacillus licheniformis NCIM 2324. Bioresour. Technol. 100, 826-832. https://doi.org/10.1016/j.biortech.2008.06.04 7

Blunt, J.W., Copp, B.R., Keyzers, R.A., Munro, M.H.G., Prinsep, M.R., 2012. Marine natural products. Nat. Prod. Rep. 29, 144-222. https://doi.org/10.1039/c2np00090c

Brockmann, H., Schmidt-Kastner, G., 1951. Resistomycin, ein neues Antibioticum aus Actinomyceten. Naturwissenschaften 38, 479-480.

https://doi.org/10.1007/BF00622090

Cai, Y., Xue, Q., Chen, Z., Zhang, R., 2009. Classification and Salt-tolerance of Actinomycetes in the Qinghai Lake Water and Lakeside Saline Soil. J. Sustain. Dev. 2. https://doi.org/10.5539/jsd.v2n1p107

Citron, C.A., Rabe, P., Dickschat, J.S., 2012. The Scent of Bacteria: Headspace Analysis for the Discovery of Natural Products. J. Nat. Prod. 75 , 1765-1776. https://doi.org/10.1021/np300468h

Elmallah, M.I.Y.Y., Micheau, O., Eid, M.A.G., Hebishy, A.M.S.S., Abdelfattah, M.S., 2017. Marine actinomycete crude extracts with potent TRAIL-resistance overcoming activity against breast cancer cells. Oncol. Rep. 37, 3635-3642.

https://doi.org/10.3892/or.2017.5595

Goodfellow, M., Williams, S.T. (Stanley T., Mordarski, M., 1988. Actinomycetes in biotechnology. Academic Press.

H. Brockmann, E. Meyer, K. Schrempp, F.R. and T.R., 1969. Die Konstitution des 
Resistomycins. Chem. Ber 102, 1224-1246.

Haupt, I., Wähnert, U., Pitra, C., Löber, G., Luck, G., Eckardt, K., 2007. Effects of the antibiotic resistomycin on the synthesis of macromolecules. Z. Allg. Mikrobiol. 15, 411421. https://doi.org/10.1002/jobm.19750150604

Höfle, G., Wolf, H., 1983. Isolierung,13C-NMRspektren und Biogenese von Resistomycin und Resistoflavin ausStreptomyces griseoflavus B 71 (Actinomycetales). Liebigs Ann. der Chemie 1983, 835-843. https://doi.org/10.1002/jlac.198319830509

Kiehlbauch, J.A., Hannett, G.E., Salfinger, M., Archinal, W., Monserrat, C., Carlyn, C., 2000. Use of the National Committee for Clinical Laboratory Standards guidelines for disk diffusion susceptibility testing in New York state laboratories. J. Clin. Microbiol. 38, $3341-8$.

Kock, I., Maskey, R.P., Biabani, M.A.F., Helmke, E., Laatsch, H., $2005 . \quad$ 1-Hydroxy-1norresistomycin and Resistoflavin Methyl Ether: New Antibiotics from Marine-derived Streptomycetes $\uparrow, \uparrow \uparrow$. J. Antibiot. (Tokyo). 58, 530-534. https://doi.org/10.1038/ja.2005.73

OKAMI, Y., HOTTA, K., 1988. Search and Discovery of New Antibiotics, in: Actinomycetes in Biotechnology. Elsevier, pp. 33-67. https://doi.org/10.1016/B978-012-289673-6.50007-5

Palanichamy, V., Hundet, A., Mitra, B., Reddy, N., 2011. OPTIMIZATION OF CULTIVATION PARAMETERS FOR GROWTH AND PIGMENT PRODUCTION BY Streptomyces spp . ISOLATED FROM MARINE SEDIMENT AND RHIZOSPHERE SOIL V Palanichamy *, Aachhari Hundet, Bhaskar Mitra and Narayana Reddy Plant Biotechnology Division, VIT Univer. Int. J.
Plant, Anim. Environ. Sci. 158-170.

Rabah, B., Lograda, T., Ramdani, M., Chalard, P., Feguiredo, G., 2013. CHEMICAL COMPOSITION AND ANTIBACTERIAL ACTIVITY OF ESSENTIAL OIL OF ZIZIPHORA HISPANICA L. Glob. J. Res. Med. Plants Indig. Med. || GJRMI || 2, 73-80.

Raja, M., Ravikumar, S., Gnanadesigan, M., Vijayakumar, V., 2010. \&lt;i\&gt;In vitro\&lt;i\&gt; antibacterial activity of diterpene and benzoxazole derivatives from \&lt;i\&gt;Excoecaria agallocha\&lt;/i\&gt; L. Int. J. Biol. Chem. Sci. 4. https://doi.org/10.4314/ijbcs.v4i3.60494

Ripa, F.A., Nikkon, F., Zaman, S., Khondkar, P., 2009. Optimal Conditions for Antimicrobial Metabolites Production from a New Streptomyces sp. RUPA-08PR Isolated from Bangladeshi Soil. Mycobiology 37, 211-4. https://doi.org/10.4489/MYCO.2009.37.3.21 1

Shiono, Y., Shiono, N., Seo, S., Oka, S., Yamazaki, Y., 2002. Effects of Polyphenolic Anthrone Derivatives, Resistomycin and Hypericin, on Apoptosis in Human Megakaryoblastic Leukemia CMK-7 Cell Line, Z. Naturforsch.

Vijayabharathi, R., Bruheim, P., Andreassen, T., Raja, D.S., Devi, P.B., Sathyabama, S., Priyadarisini, V.B., 2011. Assessment of resistomycin, as an anticancer compound isolated and characterized from Streptomyces aurantiacus AAA5. J. Microbiol. 49, 920-926. https://doi.org/10.1007/s12275-011-1260-5.

Vijayabharathi, R., Devi, P.B., Sathyabama, S., Bruheim, P., Priyadarisini, V.B., 2012. Optimization of resistomycin production purified from Streptomyces aurantiacus AAA5 using response surface methodology. J. Biochem. Technol. 3, 402-408. 
